oxalate are simply those of varying degrees of irritation of the kidneys and urinary tract.

A distinction should be made between slight, occasional deposits and large quantities occurring persistently. Almost every one has probably had at some time or another a few crystals in the urine, and these are without particular significance. But where there is frequently a considerable deposit an abnormal state must be recognized, and one which calls for treatment. The most obvious danger is the liability to the formation of calculus.

More insidious and harmful is the condition of longcontinued hyperæmia of the kidney, due to irritation, which may end in chronic interstitial nephritis, the socalled "gouty kidney." In his description of the coutracted kidney, Strumpell says: "In the pelvis of the kidney, which is often somewhat dilated, there are frequently a number of uric-acid concretions. Striated uric-acid infarctions in the pyramids are a very characteristic mark of the gouty, contracted kidney." He also says that "experience teaches us that there are three chemical substances which may favor the development of contracted kidney : alcohol, lead and uric acid. Chronic alcoholism is often to be regarded as the most probable cause of renal contraction, especially in people who have 'lived well' otherwise, and have become corpulent."

This latter condition is what we have just shown to be the most important factor in uric-acid formation, and it is not impossible that alcohol produces its harmful effect on the kidney partly through its influence in favoring the production of uric acid. Chronic leadpoisoning and gout, Striumpell also says, "often lead to the development of contracted kidney, in which we probably have to do with the noxious action of an abnormal amount of uric acid on the renal parenchyma." "Intense worry and strain of business" are causes assigned by Osler and others. These conditions also we have shown to be productive of calcic oxalate and uric acid by disordering the digestive and metabolic processes generally.

Professors Da Costa and Edward S. Wood, in recent papers, speak of the frequency with which albuminuria is produced by renal irritation caused by urine which is concentrated and contains uric acid or calcic oxalate. It is to this cause also, in many cases, that Professor Wood attributes the so-called albuminuria of adolescence.

The occurrence of albumen in these cases is often intermittent, and $I$ have found that it is much more likely to be present in the early morning urine, as this is more likely to become concentrated and to contain crystals, owing to the necessary abstinence from food and drink during the sleeping hours.

In organic nephritis, on the other hand, albumen is much more abundant after the ingestion of food, the damaged condition of the renal capillaries allowing the albumen thus supplied to go directly into the urine.

This point is illustrated by the case of a young man who came to my office one morning last April to be examined for life-insurance:

He was twenty-three years of age, a clerk in a business office, well developed and apparently in very good health. He said he felt perfectly well in every way, and there was no prejudicial family history. On examining the urine, I was surprised to find one-tenth per cent. of albumen. The urine was highly-colored, specific gravity of 1,022 , acid, without sugar, and con- tained a considerable sediment. The latter, on settling, showed under the microscope much calcic oxalate, a little mucus and a few hyaline casts. A few days later he came in in the afternoon and brought a specimen of urine passed before breakfast, which proved, on analysis, to be the same in every respect as the above, except that there was not quite so much albumen and very little calcic oxalate. The specimen passed in my office the same afternoon was of normal color, specific gravity 1,020. No albumen, sediment slight, and found to contain nothing abnormal.

On June $22 \mathrm{~d}$, after he had been taking water and diuretics, a morning specimen showed a specific gravity of 1,010 , no albumen, and a slight sediment which contained nothing abnormal. After this he neglected treatment, and I did not see him again until October 14th. On that day the early morning urine was highcolored, specific gravity 1,022, albumen one-tenth per cent., sediment slight, but contained a little calcic oxalate, a little mucus and a few hyaline casts. The afternoon specimen of the same day had a specific gravity of 1,012 , contained no albumen, and I was unable to find either calcic oxalate or casts in the urine. He informed me that a few days previously he had been accepted for life insurauce by another company, although he had informed them that he had been rejected by me in April for albuminuria. The medical examiner had had him call at his office several days in succession, and had found no albumen. On inquiry, I found that his calls had always been in the afternoon, and he was required, as is customary, to pass his water in the presence of the examiner, who became satisfied that the urine was normal. It would seem advisable in such cases with a high specific gravity for the medical examiner to contrive to secure a reliable specimen of early morning urine. I have seen the patient several times since, and usually find albumen and calcic oxalate in the morning urine. The only cause for this condition that I could discover was a habit of drinking very little water, and a disinclination to take any more exercise than he was obliged to take in walking to and from the office.

(To be continued.)

\section{CASES OF ACUTE PNEUMONIA IN CHILDREN.}

$$
\text { BY F. GORDON MORHILL, M.D. }
$$

The tables given in this paper include a great majority of the cases of pneumonia which have been treated in the wards of the Children's Hospital, the exceptions being a few of which the records are not sufficiently complete to be useful.

The period of life (second to twelfth years inclusive) during which children are eligible for admission to the hospital must be borne in mind, as it undoubtedly influences the views which experience in this particular institution might lead one to adopt.

By "frauk" pneumonia is meant a form of the disease which has been easily diagnosticated from the far more serious broncho-pueumonia, and which (so far as our experience at the Boston Children's Hospital is concerned) differs from it as radically as any two acute diseases affecting the same organs can differ in their history, course and prognosis.

The term "frank" instead of "croupous" or "fibrinous" pneumonia, is employed in order to avoid the confusion which has arisen since the comparatively 
recent discovery of the fact that there may be considerable quantities of fibrin in cases which are clinically, and (as recently proved) in their bacteriological pathology, broncho-pneumonia. The statement made that both forms and all grades of the disease may coexist in children is not warranted by our present kuowledge, and has proved a most unwelcome addition to already existing perplexities.

That a frank pneumonia may terminate by prolonged lysis, that a bronchitis often accompanies it, or that a broncho-pneumonia may involve the whole (?) or nearly the whole of an entire lobe, are facts which when properly weighed do not invalidate the statement in the preceding paragraph.

Cases of prolonged absorption of the products of a frank pneumonia are by no means rare in adult life, and the same thing is occasionally observed during childhood. Cold is assuredly a factor in the causation of trank pneumonia; and a bronchitis giving rise to râles in any or all portions of the lungs may be naturally expected in 15 to 20 per cent of all cases. When a large portion of lung is involved by a brouchopneumonia the history and predominant symptoms of the case have usually been such as to enable the attending physician to form an early and correct diagno. sis.

The very small number of autopsies which have been obtained does not warrant the expression of an opinion concerning the post-mortem appearances of either form of the disease.

Clinically, the children who have been treated in this hospital, have taken their pneumonias almost "straight."

\section{SUMMARY.}

Mortality about $1 \frac{1}{2}$ per cent. in 72 cases, of which 44 were boys, and 28 were girls.

Average age a little over five years.

Months when admitted: January, 4; February, 6; March, 6 ; April, 9; May, 7 ; June, 9; July, 2 ; August, 4; September, 5 ; October, 7 ; November, 3 ; December, 10. Spring and winter, 42 cases; summer and autumn, 30 .

Highest temperature in any case while under observation $106.5^{\circ} \mathbf{F}$. Lowest maximum temperature in any case while under observation $101^{\circ} \mathrm{F}$. Highest average maximum temperature in 68 cases $104.2^{\circ} \mathrm{F}$.

Terminating by crisis (the temperature dropping to normal or below within twenty-four hours) 34 . Terminating in "short lysis" (temperature dropping to normal or below in more than twenty-four and less than forty-eight hours) 19. By prolonged lysis 12 .

The average critical day in 54 cases was the eighth. In 31 of the cases terminating by crisis it was between the seventh and eighth. The lower lobes have been more frequently involved than any other portions of the lungs. In three cases the location of the disease was central - by which is meant that no signs of solidification could be detected, but the symptoms were sufficiently well marked to make it morally certain that the disease was frank pneumonia. Such cases as terminated in prolonged lysis, showed the physical signs of very slow absorption of inflammatory products with little or no redux crepitation. Pleuritic effusions in connection with frank pneumonia have been rare, and as a rule of small extent. But one case of empyema has been observed.

The disease certainly appears to be very benign so far as concerns the cases here reported, and the treatment has been quite simple : milk diet; brandy, when indicated; digitalis or strophanthus in cases of irregular or very weak pulse; and occasionally phenacetin, in instances when a high temperature has not been well borne. Pretty free stimulation (two or three ounces of brandy per diem) has been used when a sudden fall of temperature was followed by signs of collapse. No cough mixtures of an expectorant character have been employed; but occasionally an opiate has been given to check troublesome night-cough.

The expectoration of rusty sputa has been exceedingly rare, and the main points upon which the differential diagnosis has been made are: sudden onset of the attack (history of cough accompanied by high fever, nausea, convulsions or delirium, and abdominal pain), the quiet type of the dyspnœa and detection of solidification giving rise to coarse (as a rule) crepitant râles, bronchial respiration and exaggerated vocal resonance.

The average age of the children admitted for frank pneumouia, five years tea months, as compared with the age of those entering with broncho-pneumonia (a little over three years) would seem to show pretty conclusively that in New England the latter disease is most prevalent among children who are of an age to easily shed and rapidly proliferate the epithelium of their mucous membranes.

The following table includes the cases of bronchopneumonia which have been treated in the wards with the exception of five cases, in which the records are very incomplete. The total number of cases (33) when compared with the number of frank pneumonias (72) goes to prove which is the most common type of the disease between the second and twelfth years.

This hospital is a poor field for the observation of broncho pneumonia, which is essentially a disease of very young children and infants, and is apt to break out in epidemic form in institutions where large num. bers of them are congregated. This epidemic type is infectious, and is characterized by its sudden onset. It is this form of the disease (particularly in cases where a large extent of lung is involved) which has given rise to conflicting views of both clinicians and pathologists. The children treated in this institution are of an age which usually exempts from this fatal form of broncho-pneumonia, and the non-admission of measles affords further protection. Many of the cases reported here might be more properly called chronic bronchopneumonia, or phthisis following closely after the acute form of the disease. Cases in which an acute broncho-pneumonia is merely the death mask of a miliary tuberculosis are usually of an explosive type, and prove rapidly fatal. So far as I am aware, we have had but one example of this form of the disease in the hospital, and the diagnosis in this case was made at the autopsy.

A brief summary of the table shows that 14 of the cases were girls and 19 boys: and the average duration of illness from its commencement (as nearly as could be ascertained) in 29 cases has been between 10 and 12 weeks. There are so many types of the disease, varying from that which suddenly overwhelms a child (as in the epidemic and very infectious kind, such as occurs among children who are crowded together) to the long sickness which eventually kills by subacute or perhaps fibroid phthisis, that I think it quite impossible to fix any definite average of duration of cases which custom has sanctioned our calling 
FRANK PNEUMONIAS.

\begin{tabular}{|c|c|c|c|c|c|c|c|c|c|}
\hline$\dot{0}$ & $\dot{8}$ & 通 & 焉 & 兽运 & 急灾灾 & - & 弯 & 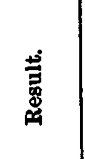 & Remarks. \\
\hline $\begin{array}{l}1 \\
2\end{array}$ & $\begin{array}{r}10 \\
8\end{array}$ & $\begin{array}{l}\mathbf{M} \\
\mathbf{M}\end{array}$ & $\begin{array}{l}\text { June } \\
\text { Aug. }\end{array}$ & $103.5^{\circ}$ & $\begin{array}{l}11 \text { th } \\
8 \text { th }\end{array}$ & $\begin{array}{l}\text { Crisis } \\
\text { Lysis, } 36 \text { hrs. }\end{array}$ & $\begin{array}{c}\text { Left lower } \\
?\end{array}$ & $\begin{array}{l}\text { Well } \\
\text { Well }\end{array}$ & $\begin{array}{l}\text { Elevation of temperature for } 48 \text { hours on 12th day. } \\
\text { Discharged well on 21st day. }\end{array}$ \\
\hline $\begin{array}{l}3 \\
4 \\
5\end{array}$ & $\begin{array}{l}4 \\
6 \\
-9 \frac{1}{2}\end{array}$ & $\begin{array}{c}\mathbf{M} \\
\mathbf{M} \\
\mathbf{F}\end{array}$ & $\begin{array}{l}\text { Dec. } \\
\text { Sept. } \\
\text { Feb. }\end{array}$ & $\begin{array}{c}102 \\
103.4 \\
?\end{array}$ & $\begin{array}{c}7 \text { th } \\
5 \text { th } \\
?\end{array}$ & $\begin{array}{l}\text { Crisis } \\
\text { Lysis, } 48 \text { hrs. } \\
\quad ?\end{array}$ & $\begin{array}{l}\text { Left lower } \\
\text { Left lower } \\
\text { Right lower }\end{array}$ & $\begin{array}{l}\text { Well } \\
\text { Well } \\
\text { Well }\end{array}$ & $\begin{array}{l}\text { Lung partially cleared up on 12th day, but solidified } \\
\text { again } 48 \text { hours later. Shortly after this the child } \\
\text { developed a broncho-pneumonia of both lungs which } \\
\text { did not entirely clear up for } 8 \text { mos. Final recovery. }\end{array}$ \\
\hline $\begin{array}{l}6 \\
7 \\
8\end{array}$ & $14 \underset{2}{\mathrm{~m}}$. & $\begin{array}{l}\mathbf{M} \\
\mathbf{F} \\
\mathbf{M}\end{array}$ & $\begin{array}{l}\text { Mar. } \\
\text { July } \\
\text { June }\end{array}$ & $\begin{array}{l}105 \\
105 \\
105\end{array}$ & $\begin{array}{r}10 \text { th } \\
8 \text { th } \\
6 \text { th }\end{array}$ & $\begin{array}{l}\text { Lysis, } 36 \text { hrs. } \\
\text { Lysis, } 48 \text { hrs. } \\
\text { Crisis }\end{array}$ & $\begin{array}{l}\text { Whole r. lung } \\
\text { Kight upper } \\
\text { Both lungs }\end{array}$ & $\begin{array}{l}\text { Well } \\
\text { Well } \\
\text { Well }\end{array}$ & Complicated with diarrhœa and whooping-cough. \\
\hline $\begin{array}{r}9 \\
10\end{array}$ & $\begin{array}{l}\mathbf{3} \\
\mathbf{7}\end{array}$ & $\underset{\mathbf{M}}{\mathbf{M}}$ & Apr. & 106 & $\stackrel{?}{\text { sth }}$ & $\begin{array}{l}\text { Lysis, } 3 \text { wks. } \\
\text { Crisis }\end{array}$ & $\begin{array}{l}\text { Left apex } \\
\text { Whole r. lung }\end{array}$ & $\begin{array}{l}\text { Well } \\
\text { Well }\end{array}$ & $\begin{array}{l}\text { Lungs } 3 \text { wks. in clearing. Chronic discharge from ears. } \\
\text { One week after the crisis the left upper lobe became } \\
\text { infected, and the temperature registered } 104^{\circ} \text { F. Res- } \\
\text { olution took place, preceded by crisis, at the end of } \\
\text { four days. }\end{array}$ \\
\hline $\begin{array}{l}11 \\
12\end{array}$ & $\frac{i \frac{1}{2}}{2 \frac{1}{2}}$ & $\begin{array}{l}\mathbf{F} \\
\mathbf{F}\end{array}$ & $\begin{array}{l}\text { Sept. } \\
\text { Jan. }\end{array}$ & $\begin{array}{l}104.8 \\
104\end{array}$ & $\begin{array}{l}\text { 7th } \\
\text { 9th }\end{array}$ & $\begin{array}{l}\text { Crisis } \\
\text { Crisis }\end{array}$ & $\begin{array}{l}\text { Left lower } \\
\text { Right upper }\end{array}$ & $\begin{array}{l}\text { Well } \\
\text { Well }\end{array}$ & $\begin{array}{l}\text { Very small extent of lung involved. } \\
\text { Child ill with whooping-cough when slse contracted } \\
\text { pneumonia. Last seen three months after admission } \\
\text { and lungs examined. Nothing wrong discovered. } \\
\text { Very slight remains of pertussis. }\end{array}$ \\
\hline 13 & 6 & $\mathbf{F}$ & Oct. & 104 & 8th & Crisis & Right lower & Well & \\
\hline $\begin{array}{l}14 \\
15\end{array}$ & $\begin{array}{l}2 \\
3\end{array}$ & $\mathbf{F}$ & $\begin{array}{l}\text { Oct. } \\
\text { Dec. }\end{array}$ & $\begin{array}{l}105 \\
104\end{array}$ & $\begin{array}{l}\text { 6th } \\
5 \text { th }\end{array}$ & $\begin{array}{l}\text { Lysis, } 36 \text { hrs. } \\
\text { Crisis }\end{array}$ & $\begin{array}{l}\text { Iefet lower } \\
\text { Central }\end{array}$ & $\begin{array}{l}\text { Well } \\
\text { Well }\end{array}$ & $\begin{array}{l}\text { Very small extent of lung involved. } \\
\text { No solidification detected; a few râles in both sides of } \\
\text { chest, rapid respiration and all the usual signs of } \\
\text { frank pneumonia, including the theometric indica- } \\
\text { tions. }\end{array}$ \\
\hline 16 & 5 & $\mathbf{F}$ & Mar. & 105 & 8th & Lysis, 108 hrs. & Left lower & Well & \\
\hline $\begin{array}{l}17 \\
18\end{array}$ & $\begin{array}{r}7 \\
10\end{array}$ & $\begin{array}{l}\mathbf{M} \\
\mathbf{M}\end{array}$ & $\begin{array}{l}\text { Apr. } \\
\text { Apr. }\end{array}$ & $\begin{array}{l}104.5 \\
105\end{array}$ & $\begin{array}{l}\text { 5th } \\
7 \text { th }\end{array}$ & & & $\begin{array}{l}\text { Well } \\
\text { Well }\end{array}$ & Very slight. Location not discovered until 5th day. \\
\hline 19 & 2 & $\mathbf{M}$ & Dec. & 105.2 & 10 th & Crisis & Entire r. lung & Well & 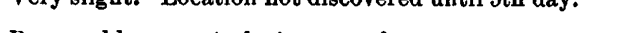 \\
\hline 20 & 11 & $\hat{\mathbf{M}}$ & Feb. & 102.5 & 14th & Lys & Right lower & ? & Removed by parents during convalescence. \\
\hline $\begin{array}{l}21 \\
22\end{array}$ & $\begin{array}{r}10 \\
8\end{array}$ & $\stackrel{M}{M}$ & $\begin{array}{l}\text { June } \\
\text { Oet. }\end{array}$ & $\begin{array}{l}105 \\
105\end{array}$ & $\begin{array}{l}\text { 9th } \\
\text { 5th }\end{array}$ & is 6 dys. & Rig & $\begin{array}{l}\text { Well } \\
\text { Well }\end{array}$ & Spinal caries. \\
\hline 23 & $\begin{array}{r}5 \\
10\end{array}$ & $\underset{\mathbf{F}}{\mathbf{F}}$ & $\begin{array}{l}\text { Jan. } \\
\text { Aug. }\end{array}$ & 104 & $\begin{array}{l}\text { 7th } \\
\text { 9th }\end{array}$ & $\begin{array}{l}\text { Crisis } \\
\text { Crisis }\end{array}$ & $\begin{array}{l}\text { Left lower } \\
\text { Right apex }\end{array}$ & $\begin{array}{l}\text { Well } \\
\text { Well }\end{array}$ & \\
\hline 25 & $7 \frac{1}{4}$ & $\mathbf{F}$ & Dec. & 106 & 8 th & Lysie, $48 \mathrm{hrs}$. & Right upper & Well & $\begin{array}{l}\text { Temperature after rapidly dropping to } 100^{\circ} \mathrm{F} \text {., imme- } \\
\text { diately rose to } 104^{\circ} \text {, from which point it dropped to } \\
\text { subnormal after } 24 \text { hours. }\end{array}$ \\
\hline $\begin{array}{l}26 \\
27\end{array}$ & $\begin{array}{l}6 \\
5\end{array}$ & $\begin{array}{l}\mathbf{M} \\
\mathbf{M}\end{array}$ & $\begin{array}{l}\text { Nov. } \\
\text { Nov. }\end{array}$ & $\begin{array}{r}104 \\
?\end{array}$ & $?$ & Lysis, 20 dys. & $\begin{array}{l}\text { Right lower } \\
\text { Rjght lower }\end{array}$ & $\begin{array}{l}\text { Well } \\
\text { Well }\end{array}$ & tical day," \\
\hline 28 & 21 & M & July & 105 & $\stackrel{?}{?}$ & $\begin{array}{l}\text { Crisis } \\
\text { Lysis, } 48 \text { hrs. }\end{array}$ & Left lower & Well & No history obtainable. \\
\hline 30 & $\begin{array}{r}11 \\
2\end{array}$ & $\stackrel{\mathbf{H}}{\mathbf{M}}$ & $\begin{array}{l}\text { Dec. } \\
\text { Feb. }\end{array}$ & $\begin{array}{l}104 \\
104.2\end{array}$ & 1oth & & & $\begin{array}{l}\text { Well } \\
\text { Well }\end{array}$ & \\
\hline 31 & $\overline{\mathbf{5}}$ & $\vec{M}$ & Mar. & 106 & 8th & & & & \\
\hline $\begin{array}{l}32 \\
33\end{array}$ & $\begin{array}{l}\mathbf{9} \\
\mathbf{2}\end{array}$ & $\stackrel{\mathbf{N}}{\mathbf{M}}$ & $\begin{array}{l}\text { Apr. } \\
\text { May }\end{array}$ & $\begin{array}{l}104.5 \\
104\end{array}$ & $\stackrel{5+h}{?}$ & $\begin{array}{l}\text { Crisis } \\
\text { Crisis }\end{array}$ & $\begin{array}{l}\text { Right lower } \\
\text { Right upper }\end{array}$ & $\begin{array}{l}\text { Well } \\
\text { Well }\end{array}$ & No history obtainable. \\
\hline 35 & 5 & $\mathbf{M}$ & June & 105 & $\cdots$ & .... & Whole r. lung & Died & $\begin{array}{l}\text { "Delicate for months." Child very emaciated and } \\
\text { suffering from a bad diarrhoa when admitted to the } \\
\text { house. Death occurred on the 4th day after entrance. } \\
\text { A well-marked case of frank pneumonia of the apex } \\
\text { complicating typhoid. No definite bistory obtain- } \\
\text { able. }\end{array}$ \\
\hline 36 & 6 & $\mathbf{M}$ & June & 104 & 14th & Crisis & Left upper & Well & \\
\hline 37 & 8 & $\mathbf{M}$ & Oct. & 103.8 & 8 th & Lysis, 4 dys. & Right lower & Well & $\begin{array}{l}\text { Pleuritic effusion over affected lung } 4 \text { days after reso- } \\
\text { lution. Temperature rose to } 102^{\circ} \text {. Effusion promptly } \\
\text { absorbed. }\end{array}$ \\
\hline 38 & 8 & $\mathbf{F}$ & Apr. & 104.5 & 8th & Cris & Ieft lower & Well & \\
\hline 39 & 5 & M & Féb. & 103 & 11 th & , 36 hrs. & Left lower & Well & $\begin{array}{l}\text { Temperature on the } 11 \text { th day fell to } 99.2^{\circ} \mathrm{F} \text {. A pleu- } \\
\text { ritic effusion over affected lung immediately caused } \\
\text { it to rise to } 102^{\circ} \mathrm{F} \text {. }\end{array}$ \\
\hline 10 & 3 & $\mathbf{F}$ & Apr. & $?$ & $?$ & $?$ & Left upper & Well & $\begin{array}{l}\text { Temperature chart missing. Convulsions during first } \\
\text { three days of illness. }\end{array}$ \\
\hline $\begin{array}{l}41 \\
42\end{array}$ & 3 & $\underset{M}{\mathbf{F}}$ & Apr. & 105 & 12th & $\begin{array}{l}\text { Lysis, } 36 \text { hrs. } \\
\text { Crisig }\end{array}$ & Right lower & Well & 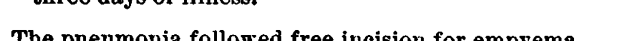 \\
\hline 43 & $4^{32}$ & $\mathbf{M}$ & Aug. & 103 & $?$ & Lysis, 30 dys. & Left lower & Well & $\begin{array}{l}\text { obstinate diarrhoea. A necrosis of inferior maxilla } \\
\text { was discovered and operated upon, after which the } \\
\text { lung finally cleared up, sixty days after commence- } \\
\text { ment of illuess. }\end{array}$ \\
\hline $\begin{array}{l}44 \\
45\end{array}$ & $\begin{array}{r}8 \\
10\end{array}$ & $\stackrel{\mathbf{M}}{\mathbf{F}}$ & $\begin{array}{l}\text { Oct. } \\
\text { Dec. }\end{array}$ & $\begin{array}{l}104.5 \\
106\end{array}$ & $\begin{array}{l}\text { 4th } \\
\text { 8th }\end{array}$ & $\begin{array}{l}\text { Lysis, } 3 \text { dys. } \\
\text { Lysis, } 48 \text { hrs. }\end{array}$ & $\begin{array}{l}\text { Left lower } \\
\text { Left upper }\end{array}$ & $\begin{array}{l}\text { Well } \\
\text { Well }\end{array}$ & $\begin{array}{l}\text { Said to be third attack. } \\
\text { Temperature fell suddenly to } 99^{\circ} \mathrm{F} \text {. on } 3 \mathrm{~d} \text { day. Child } \\
\text { in a condition of collapse from which slie rallied } \\
\text { after free stimulation. }\end{array}$ \\
\hline 46 & 5 & $\mathbf{F}$ & Nov. & 106 & 13th & Lysis, 48 hrs. & Both lower. Jobes & Well & $\begin{array}{l}\text { Reinfection of right lung on the } 3 \mathrm{~d} \text { day after entrance. } \\
\text { The temperature which had dropped to } 102^{\circ} \mathrm{F} \text {., } \\
\text { promptly rose to } 105^{\circ} \mathrm{F} \text {. }\end{array}$ \\
\hline 47 & 8 & $\mathbf{M}$ & Jan. & 104 & 10th & Lysis, $48 \mathrm{hrs}$. & Left lower & Well & $\begin{array}{l}\text { Second attack in this institution (see case } 44 \text { ) said to } \\
\text { be the 4th in all. }\end{array}$ \\
\hline 48 & $2\}$ & $\mathbf{F}$ & May & 106 & $?$ & Lysis, 2 dys. & Central & Well & $\begin{array}{l}\text { No history obtainable. No solidification of lung de- } \\
\text { tected, but all the rational signs of frank pnen- } \\
\text { monia. }\end{array}$ \\
\hline 49 & $2 \frac{1}{2}$ & $\mathbf{F}$ & Sept. & 104 & 8th & Lysis & Left apex & $?$ & Child removed by parents while temperature was de- \\
\hline $\begin{array}{l}50 \\
51\end{array}$ & $\mathbf{5}$ & $\mathbf{M}$ & Sept. & 103 & 5 th & $\begin{array}{l}\text { Crisis } \\
\text { Lysis, } 48\end{array}$ & $\begin{array}{l}\text { Right lower } \\
\text { Left apex }\end{array}$ & $\begin{array}{l}\text { Well } \\
\text { Well }\end{array}$ & \\
\hline 52 & 8 & $\mathbf{F}$ & Sept. & 306 & 12 th & Crisis & Right lower & Well & $\begin{array}{l}\text { Delirium from commencement of illness until } 3 \text { days } \\
\text { after the temperature had descended to normal. } \\
\text { Lung did not entirely clear up until } 2 \text { months after } \\
\text { crisis. Meallwile fever of very irregular type and } \\
\text { symptoms of some obstinate subacute lung trouble, } \\
\text { which gradually disappeared. }\end{array}$ \\
\hline $\begin{array}{l}53 \\
54 \\
55 \\
56\end{array}$ & $\begin{array}{l}6 \\
2 \\
3 \\
5\end{array}$ & $\begin{array}{l}\mathbf{F} \\
\mathbf{F} \\
\mathbf{F}\end{array}$ & $\begin{array}{l}\text { Dec. } \\
\text { Dec. } \\
\text { Jan. } \\
\text { Mar. }\end{array}$ & $\begin{array}{l}106.5 \\
103 \\
106 \\
105.6\end{array}$ & $\begin{array}{l}\text { 11th } \\
\text { 7th } \\
\text { 8th } \\
\text { 1nth }\end{array}$ & $\begin{array}{l}\text { Crisis } \\
\text { Lysis, } 48 \text { hrs. } \\
\text { Lysis, } 5 \text { dys. } \\
\text { Crisis }\end{array}$ & $\begin{array}{l}\text { Left lower } \\
\text { Left lower } \\
\text { Right lower } \\
\text { Central }\end{array}$ & $\begin{array}{l}\text { Well } \\
\text { Well } \\
\text { Well } \\
\text { Well }\end{array}$ & Of very slight extent. \\
\hline 57 & 7 & $\mathbf{M}$ & Mar. & 105 & 12 th & Lysis, 48 hrs. & Right upper & Well & $\begin{array}{l}\text { A central pneumonia which was not located so far as } \\
\text { physical sigus are concerned until the 6th day of the } \\
\text { disease. }\end{array}$ \\
\hline 58 & 9 & $\mathbf{M}$ & Feb. & 105 & $?$ & Lysis & Entire left lung & Well & $\begin{array}{l}\text { No eritical day. Prolonged lysis. The pneumonia com- } \\
\text { plicated by both peri- and endo-carditis. The lung } \\
\text { cleared entirely at the expiration of } 6 \text { weeks. }\end{array}$ \\
\hline
\end{tabular}




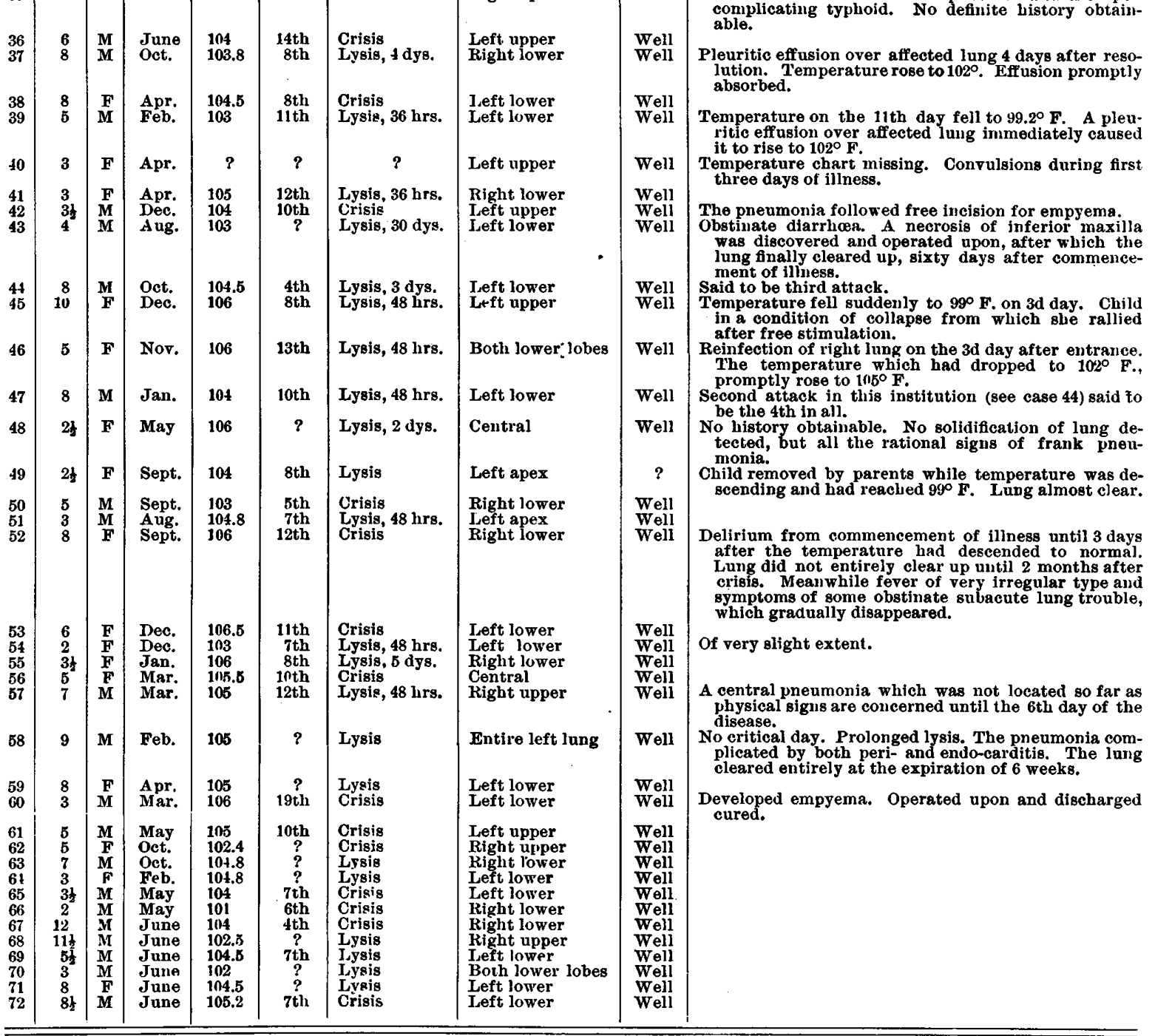

BRONCHO-PNEUMONIAS.

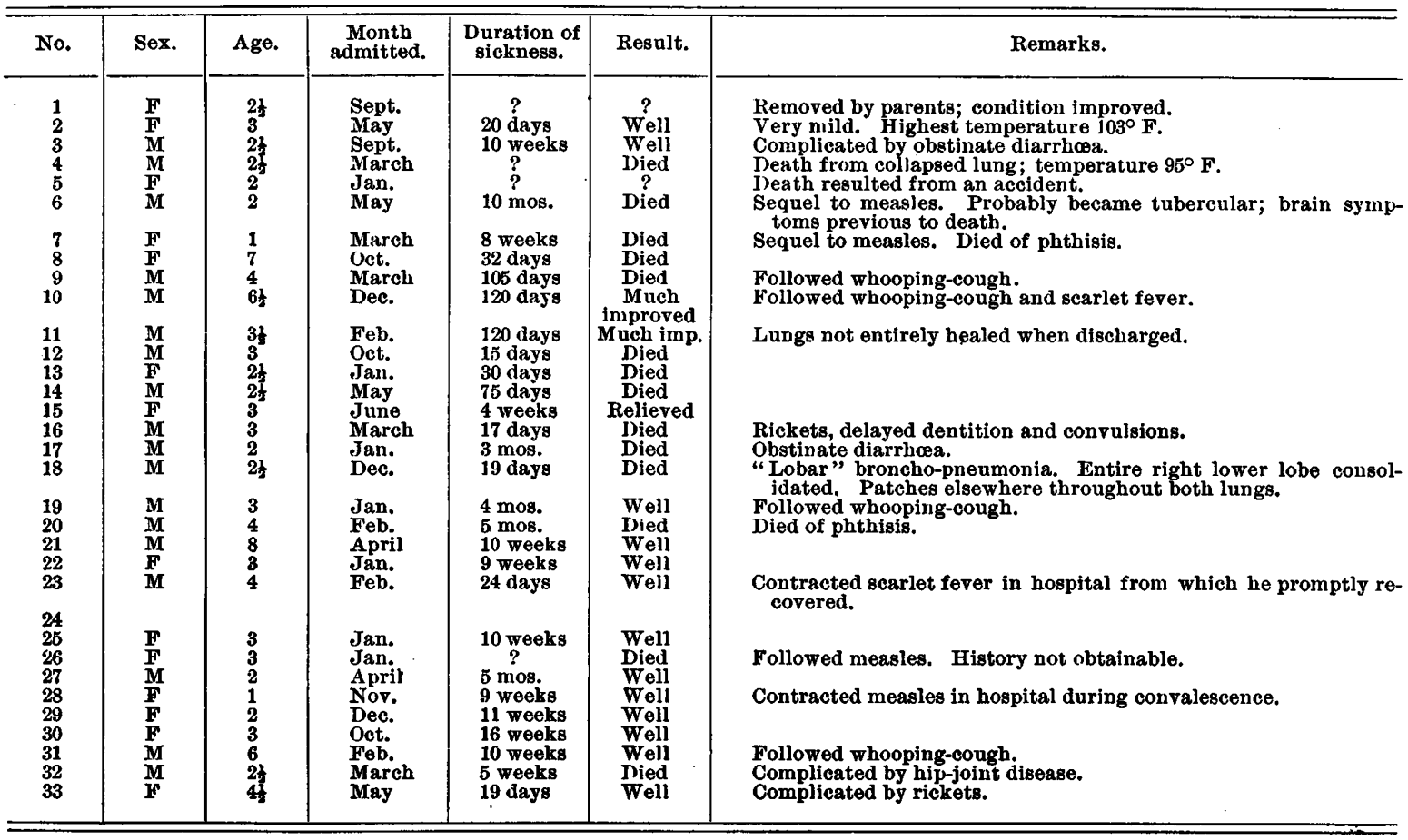


" broncho-pneumonia." A very acute attack may prove to be merely the wind-up of a miliary tuberculosis; it may kill in a very few days without the aid of tubercle, or the child may recover quite speedily. On the other hand, a similar attack may be followed by a slow form of pulmonary phthisis; and the period of death, or possibly recovery, is quite indefinite. A mortality of 45 per cent. as in the cases here given, is perhaps what might be naturally looked for in the type of the disease which they represent.

I have been unable to discover in the records any case of so-called "capillary bronchitis," for the reason that when children have presented the symptoms usually attributed to this disease (as they have in one or two instances) they have been treated for, and recovered or died of, broncho-pneumonia.

\section{MQQuital Brogregiz.}

\section{REPORT ON THERAPEUTICS.}

BY FRANCIS H. WILLIAMs, M.D.

THE UNTOWARD EFFECTS OF ANTIPYRIN, ACETANILIDE and Phenacetin.

Dr. D. R. Patrerson ${ }^{1}$ states that circulars were sent out to the South Wales Branch of the British Medical Association asking for information as to the alleged ill effects following the administration of antipyrin, acetanilide and phenacetin, the nature and comparative frequency of their occurrence, and their relative importance. Twenty-five replies were received; and these were from men engaged in active practice, in some instances both hospital and private, and residing in different parts of the district. The writer also discussed the subject with many of the members who sent in reports, and thus learned their views at greater length than could be expressed in a circular reply.

Antipyrin. - It is as an analgesic that this drug is prescribed so largely by practitioners, and all are agreed that it is an invaluable remedy. Large doses depress the nervous system. Of the twenty-five reports, seventeen note positive results, varying from an unpleasant diaphoresis to severe collapse. Most of them may be referred to the action on the nervous system, producing exhaustion and collapse following the fall of temperature; and there may be disturbance of the circulation for the same reason or secondarily from the effect on the blood-corpuscles and the production of methæmoglobinæmia. Other symptoms, such as affections of the skin and pronounced psychical disturbance, are more rare. Depression with collapse has usually been noticed after doses given with a view to reduce fever. Thus, a dose of twenty grains was followed in a male adult in a short time by great collapse and fall of temperature, requiring hypodermic injections of ether and digitalis to tide the patient over the difficulty. The writer cites another case in which ten grains given to a lady convalescent from influenza led to extreme depression and collapse; the patient became deeply cyanosed, unconscious and pulseless, and required free stimulation before she was considered out of danger twelve hours later. A small proportion of results such

1 The Practitioner, 1893. as these have been observed in children, where regulation of the dose is not 80 exactly carried out, although the amount borne by a child is often relatively much larger.

Several of the reports call attention to the frequency of depression in pneumonia, and express the opinion that the use of the drug should be very guarded in that disease, one member holding that it is positively harmful even in small amounts. Falk, in his résumé of the ill effects of recently introduced antipyretics, mentioned a case of pneumonia where death occurred one hour after the administration of antipyrin, which was regarded as the cause of the fatal result. The stage of collapse is not infrequently ushered in by a feeling of anxiety and great prostration, and the symptoms are sometimes relieved by vomiting. The intensity of depression that may follow even a moderate quantity of antipyrin is illustrated by a case, recorded by the late Paul Guttmann, which was sent into the hospital as one of cholera. The patient, a well-developed man, had the symptoms and appearance of the asphyxial stage of cholera-morbus, except that the bowels were confined. On the chest and abdomen was a dull-red miliary rash. Five days previous to his admission, he had taken for headache a fifteen-grain powder of antipyrin twice a day, in all 150 grains, when he fell into this condition. Under stimulating treatment he recovered rapidly. Minor degrees of depression are represented by unpleasant diaphoresis, which may be so profuse as to prostrate the patient temporarily. Continued use of even small doses leads not infrequently to a condition in which the patient complains of loss of energy, is disinclined to exert himself and becomes depressed mentally, in short, there is established an antipyrin habit. Falk mentions headache, giddiness and other nervous symptoms as occssionally brought on by antipyrin.

One of the members report blurring of the vision along with blueness of the lips and finger-nails. Blueness of the lips and face is one of the commonest untoward effects, and was noticed in various degrees, from that which is just perceptible, to a deep cyanosis associated with profound collapse. It is to be ex. plained by the action on the nervous system, and especially the blood by which methæmoglobinæmia is pro. duced. In extreme doses the red cells are destroyed. The circulation of the altered blood through the medullary centres is responsible for many of the symptoms observed.

Several of the reports note cardiac depression. Cardiac failure in cases of pneumonia was frequent even with doses of ten grains. None of the members have apparently had any experience of the occurrence of hæmorrhages reported by Continental writers. Such an occurrence points to the necessity of great caution in the administration of antipyrin in phthisis and ty. phoid fever. In the former, the rather profuse perspiration produced by the drug is a serious drawback. Two of the reports mention the appearance of a rash after the use of antipyrin. 'The writers of these reports did not observe various symptoms observed by others, such as convulsions, rise of temperature instead of the anticipated fall, etc.

As to the frequency with which the ill effects are met, all the members agreed that they were very rare. Shortly after the introduction of the drug they were not uncommon, on account, no doubt, of the larger doses then in use. The reports of those who have not 